\title{
THE HISTORIC CORES AND THE NATIONAL CONCEPTIONS \\ OF THE SOUTH SLAVS
}

\author{
DOI: http://dx.doi.org/10.18509/GBP.2016.46
}

UDC: $323.1: 316.75(=163)$

\author{
Jurica Botić \\ Ministry of Science, Education and Sports, Croatia
}

\begin{abstract}
The aim of this article is to determine the influence of the relations between historic and political cores on the evolution of the conceptions of national ideologies of South Slavs. The methodological framework of the research consists of the combination of using the historical and comparative methods in determining the conclusions for each of the South Slavic ethnic groups. Various theoretical approaches in the field of ethnic and national studies, as well as in the field of geopolitical terminology, were used as a theoretical framework in drafting the article. By highlighting the key terms, the article defines the meaning of terms of the historic and political cores, and ethnic and territorial conception of nation. In addition, through separate analysis of the relations between historic and political cores and their impact on the conceptions of national ideologies, article confirmed the basic hypothesis that overlapping of the historic and political cores generally causes the development of the territorial conception of South Slavic nations, while spatial deviation of these two cores usually leads to the development of ethnic conception of the nation. Also, in the case of the South Slavic nations with predominant ethnic conception of the nation, there are noticeable tendencies to territorial revisionism, while in the case of the territorial nations, the tendencies to reductionist identity and detention in their own historic and political cores can be noticed.
\end{abstract}

Key words: historic core, political core, ethno-nationalism, territorialisation, South Slavs

\section{INTRODUCTION}

The area of the Southeast Europe is usually viewed as a space of great ethnical and religious heterogeneity which caused a high level of territorial fragmentation of this area, in the literature highlighted by the term of balkanization. Since the balkanization of contemporary political map of Southeast Europe is more obvious in the western part of the region, or in the so-called western Balkans which largely spatially coincides with the territory of the former Yugoslavia, it is necessary to devote more attention to the causes of such political-geographical configuration of this part of Europe, whose roots can be found in the prevailing national conceptions of the ethnicities who live here, and on the historical and geographical conditionality of these conceptions, taking into account the spatial correlation of their historic and political core. Therefore, this article deals with national conceptions of the South Slavs, whereby the article is limited to the nations of the former Yugoslavia, and therefore the Bulgarian nation is not included in the scope of the present article. 


\section{THE AIMS AND THE RESEARCH METHODOLOGY}

The aim of this article is to determine the influence of the relations between historic and political cores on the evolution of the conceptions of national ideologies of South Slavs. More specifically, the aim of this research is to determine the existence of a correlation between the territorial deviation and geographical distances between historic and political core of the concrete nation on one hand, and predominant of the ethnic or territorial conception of national ideology on the other.

In terms of methodology, by using the historical method the article tries to identify and to interpret the relationship of historic and political core of each of researched nations cartographically. Furthermore, by using the same method, as well as the theoretical framework of the theorists in the field of ethnic and national studies, the article tries to present a predominant conceptual framework of the interpretations of each of South Slavic nations. Finally, by using the methods of comparison and synthesis of each of the analysis results, the article is going to determine the fundamental aim of the research the applicability of generalizing of the correlation between the relations of historic and political cores and the predominant national conceptions among the South Slavs.

\section{DEFINITIONS AND THE THEORETICAL FRAMEWORK OF RESEARCH}

Based on theoretical assumptions of American author Saul B. Cohen, the article delves into the scientific area of political geography by naming and interpreting the meaning of concepts of historic and political core, and also, by applying of Cohen's theoretical approaches to the interpretation of political and geographical realities in the area of former Yugoslavia. On the other hand, the article also relies on theoretical perspectives of modern authors in the interpretation of the origin and forms of contemporary South Slavic nations. Moreover, the article contrasts ethnic (ethno-religious) and the territorial conception of nation as the two basic models of constructing the nation in this area.

\section{HISTORIC AND POLITICAL CORE}

According to Saul B. Cohen, historic and political cores are just two of geopolitical features of geopolitical structures. This author defines historic or nuclear core as "the area in which a state originates, and out of which the state-idea has developed". Cohen adds that "the relationship between the physical environment of the core and the politicalcultural system that evolves may become embedded and persist as an important element of national or regional identity and ideology". According to Cohen, capitals or political core "serves as the political and symbolic focus of activities that govern the behaviour of people in a politically defined territory" with "considerable symbolic value in mobilizing support for the state" [1].

\section{ETHNIC AND TERRITORIAL CONCEPTIONS OF THE NATION}

In simplified terms, territorial and ethnic model are two basic models of forming a nation. According to the classical modernist Hans Kohn and his theory on the eastern and western nationalisms, separated by the river Rhine, the western nationalism (usually territorial) is rational and voluntary type, while the eastern one (mostly ethnic) is organic type. Along with civil territorial type of nation developed in France and ethnic type of genealogical approach originated in Germany, Anthony D. Smith adds the plural type in immigrant societies [2]. Therefore, this article is going to accept a theoretical discourse of these authors as the leading representatives of earlier and recent researchers of nations and nationalism, with no intention of entering into a theoretical discussion of the genesis of 
the nation as a phenomenon. Thus, the article distinguishes the territorial conception based on ius solis and ethnic conception based on ius sanguinis.

\section{THE RELATION AMONG THE HISTORIC CORES AND THE NATIONAL CONCEPTIONS IN EUROPE}

Historical experiences show that the territorially conceived nations are less disposed to expansionism, while at the same time this kind of nation is more disposed to denial of pluralism of identities within the boundaries of the nation-state. On the other hand, the ethnically conceived nations are usually disposed to observe national borders in the broadest possible form, so they are traditionally disposed to revisionist and expansionist policy. Let we consider a few examples nations in Europe and worldwide and their position within the presented scheme.

France is a typical example of territorially conceived nation. In fact, despite numerous regional identities, France is an excellent example of constituting of a unified nation on a territorial basis (ius solis), while the high level of centralization of the state and the continuous spatial coincidence of historic and political cores have certainly contributed to that fact.

On the other hand, the German ethnic area is characterized by polycentrism of historic cores, while the location of the political core in Berlin was mainly caused by elimination of Vienna from the race for dominance among the German states in the $19^{\text {th }}$ century. Therefore, in the German case, we cannot find the historic and political core at the same location, except in the case of Prussia, but not in Germany as a whole. Also, the lack of traditional territorialisation of identity makes predominant ethnic conception of the German nation (ius sanguinis) more than understandable.

In the case of Italy, the lack of unique historic core has been successfully overcome by the use of Rome and its role in ancient times as a cohesive element of all Italians, despite the fact that Piedmont had enough reasons to emphasize its own role in the unification and formation of the Italian nation. Therefore, as the Italian nation makes an atypical exception regarding the correlation of historic and political core, in a similar way, it makes the conceptual exception in national terms. Specifically, while the territorial conception of the nation dominates on inner plane based on Italy as a geographical and regional term, Italian territorial claims were based on the ethnic principle (and questionable historical right) on external plane.

The United States present an interesting example of correlation of the historic and political core in the formation of the nation in which the foundation of the country, the formation of the nation and the foundation of the new capital were the parallel processes. Here we cannot talk about any other American urban centre, or even about Boston, as a kind of alternative historic or political core, especially if we keep in mind, for American conditions, the minimum spatial distance and similar historical and political context of Boston and Washington. Besides that, as an immigrant nation with a strong need for assimilation (melting pot), Americans are a typical example of territorial conceived nation.

\section{THE RELATION AMONG THE HISTORIC CORES AND THE NATIONAL CONCEPTIONS OF THE SOUTH SLAVS}

Specific circumstances of development of the South Slavic nations caused specific types of modification of the classical understanding of ethnic and territorial nationalism among 
them. In fact, the circumstances of historical reterritorialization of the South Slavic ethnic areas within the administrative-territorial framework of Austro-Hungarian and Ottoman empires, as well as the equalization of meaning of ethnic and religious identities of the population, caused the great national and political fragmentation called balkanization. Since that the same or similar conditions in various South Slavic peoples haven't obligatory caused the same national conceptions, it is necessary to compare the role of historic and political cores in the formation of these conceptions.

\section{SLOVENES}

The historic core of Slovenia is located almost entirely outside of the political space of modern Slovenia, and covers the historical Carantania in the area of today's federal state of Carinthia (Kärnten) in Austria and southern slopes of the Alps in the Slovenian Carinthia (Koroška) [3]. Despite the systematic reduction of the Slovenian ethnic territory, especially under the influence of strong Germanization, Slovenes were able to retain their ethnic and linguistic particularity and develop their own national identity exclusively on ethnic basis with a national name based on the general Slavic ethnic name.

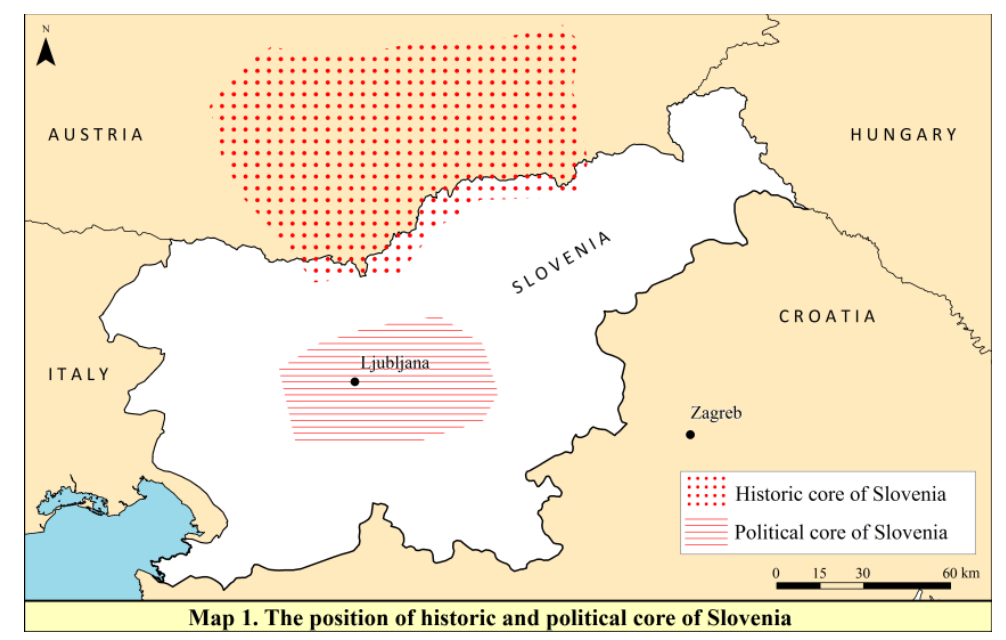

According to the fact that a large part of Slovenes remained outside of their national state, it should be noted that in period of formation of the Slovenian nation in the $19^{\text {th }}$ century, Klagenfurt in today's Austria and Trieste in today's Italy were important centres of Slovenian national revival. This extreme example, where historic core is completely absent from contemporary national territory, and thus crucial deviates from contemporary political core, fully confirms the hypothesis of overcoming ethnic conception of the nation in the circumstances of deviations of political from the historic core.

\section{CROATS}

Croatian historic core is located in the area of northern and central Dalmatia [4], about $300-350 \mathrm{~km}$ to the south in relation to contemporary political core. The political centre of the Croatian state through the centuries gradually moved northward as a result of reduction of Croatian territory caused by invasions of foreign conquerors. Because of the territorial limitation of Croatian political space as part of the Austro-Hungarian Empire, concentrated in the area of contemporary political core of Croatia in the wider region of the city of Zagreb in Central Croatia, Croats gradually totally rejected territorial conception of nation and opted exclusively for ethnic one. Specifically, despite the fact 
that the Croatian ethnic area until the beginning of the $20^{\text {th }}$ century was entirely under the rule of the Dual Monarchy, the same space was not unique in administrative-territorial sense, but was divided between Vienna and Budapest.

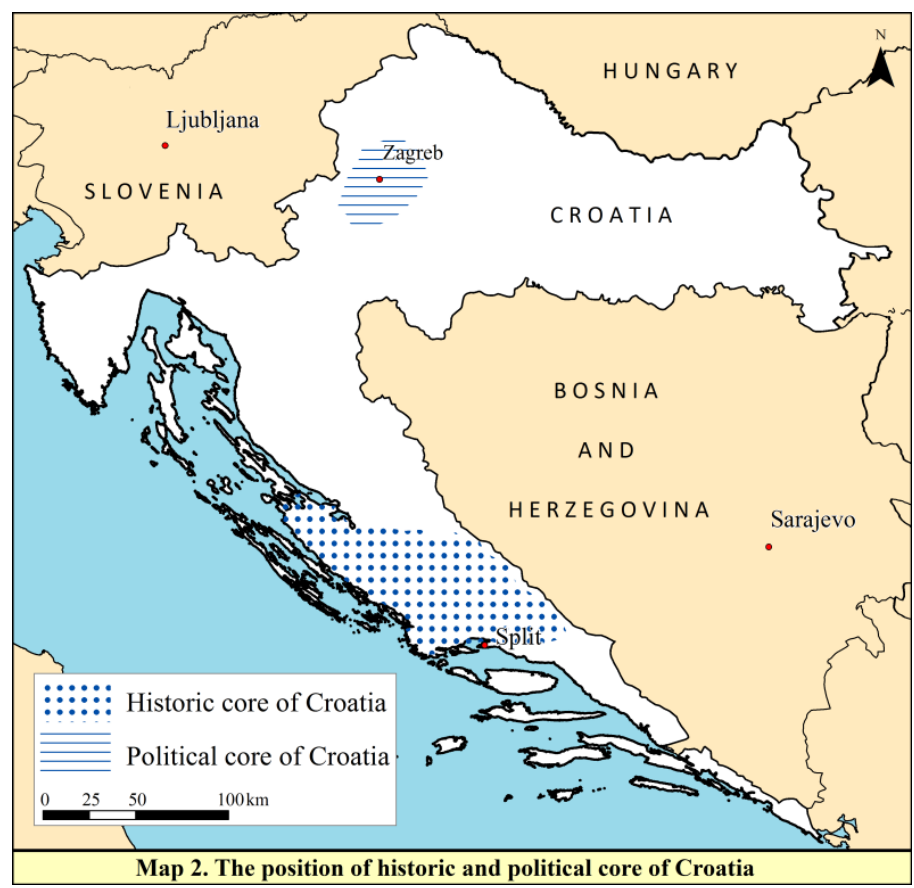

Despite strong regional identities within the Croatian ethnic space, ethnic affiliation is maintained as a strong cohesive element through the past, so thus ethnic identity more effectively enable the development of national identity of Croats. By including religious affiliation as a national differentia specifica, Croatian identity was gradually strongly established among Catholics in Bosnia and Herzegovina that in some periods included the territorial revisionism. Finally, in the case of Croats, the ethnic conception of the nation in the case of the spatial deviation of political from the historic core has also been found.

\section{BOSNIAKS}

The historic core of the medieval Bosnia largely spatially overlaps with the area of contemporary political core of Bosnia and Herzegovina, and covers an area of the upper course of the river Bosna, nowadays mostly bordered within the limits of the Sarajevo Canton in the entity of the Federation of Bosnia and Herzegovina. Although the territorial conception of the nation in this land exclusively characterizes the Bosniaks, it is easy to conclude that spatial coincidence of historic and political core of Bosnia and Herzegovina confirms an initial assumption that such circumstances produce exactly the territorial conception of the nation. It is also important to highlight that, due to Dayton Peace Agreement, within this country exist a kind of secondary political core with the centre in Banja Luka in the entity of Republic of Srpska.

However, previous extensively and in state-sense integrative interpreted territorial conception of the Bosniak identity gradually adopts a reduced form of identity on a strong ethno-religious basis which includes exclusively Muslim population of Bosnia and Herzegovina, but also the Slavic Muslim population outside the borders of this country, especially in the Sandžak region in Serbia and Montenegro [5]. 


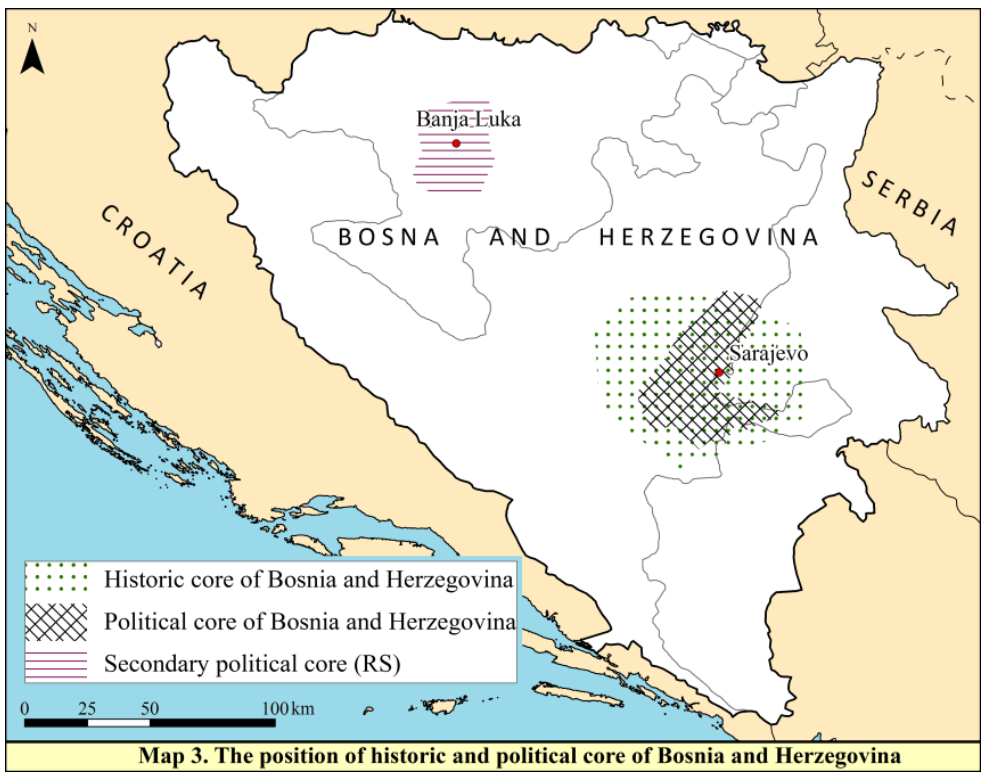

Therefore, the Bosniak national identity is an example in which, due to the reduction of territorial identity, the ethnicization of identity, with the possibility of territorial revisionism, takes an initiative.

\section{SERBS}

Much like in the case of Croats, Serbian political core moved about $400 \mathrm{~km}$ to the north in relation to the historic core, so Serbian ethnically conceived nation in a similar way confirms the hypothesis of the article.

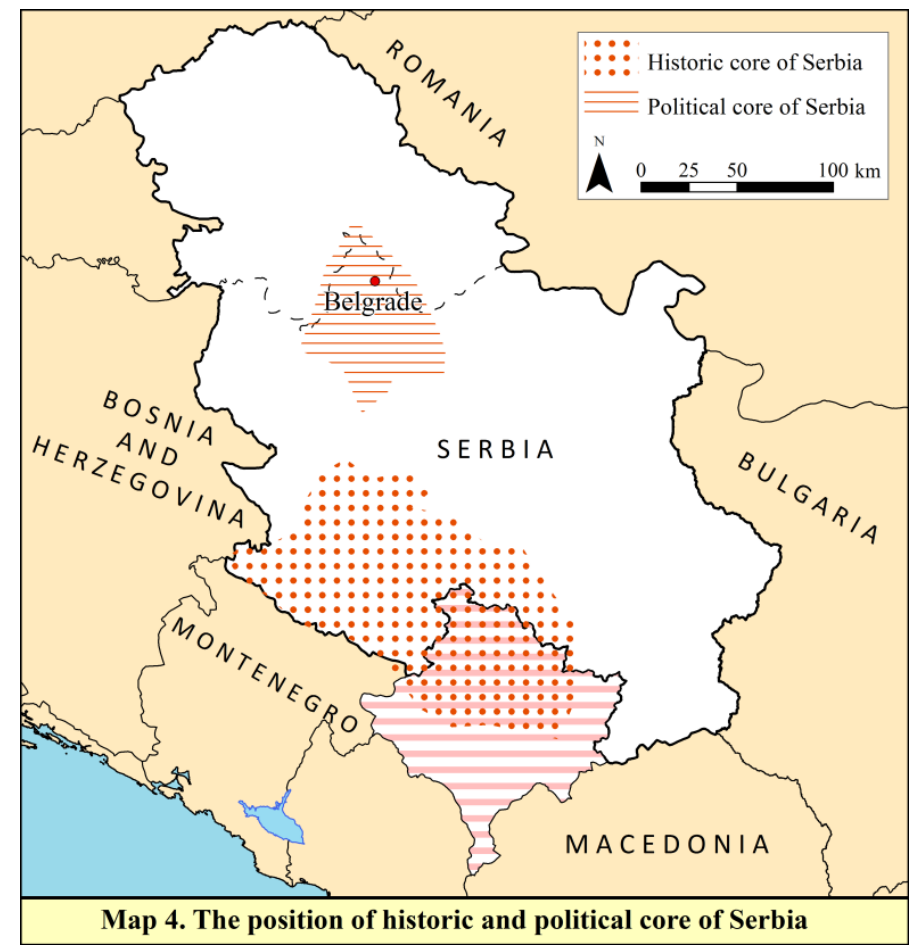

However, in the case of Serbs, the ethnic conception of the nation did not replace previous territorial one, but due to ethno-religious differentiation preserved thanks to the strong 
role of the Serbian Orthodox Church, this conception was dominant among the Serbs from the beginning of national forming. In addition, the lack of their own autonomous territorial-political organization within the Ottoman Empire before the Serbian uprisings in the $19^{\text {th }}$ century, necessary led the Serbian national ideology to the ethnicization of identity with a strong need of territorial expansion on the territory of Bosnia and Herzegovina, Montenegro, Macedonia and parts of Croatia with significant Orthodox community [6].

However, in the contemporary circumstances of the declaration of independence of Kosovo, in which Serbia de facto lost control over much of its historic core, the formation of a new territorial identity in the Republic of Srpska, as a part of Bosnia and Herzegovina with Serbian majority, creates a sense of symbolic compensation for lost territory, while this identity is in the subordinate position in relation to the Serbian national identity in whole designed on ethno-religious basis.

\section{MONTENEGRINS}

Initially territorially conceived the Montenegrin nation, also without significant deviations between the historic and political core, gradually, much like the Bosniak nation, adopted a reduced ethnic model of interpretation of the nation, but with two important differences.

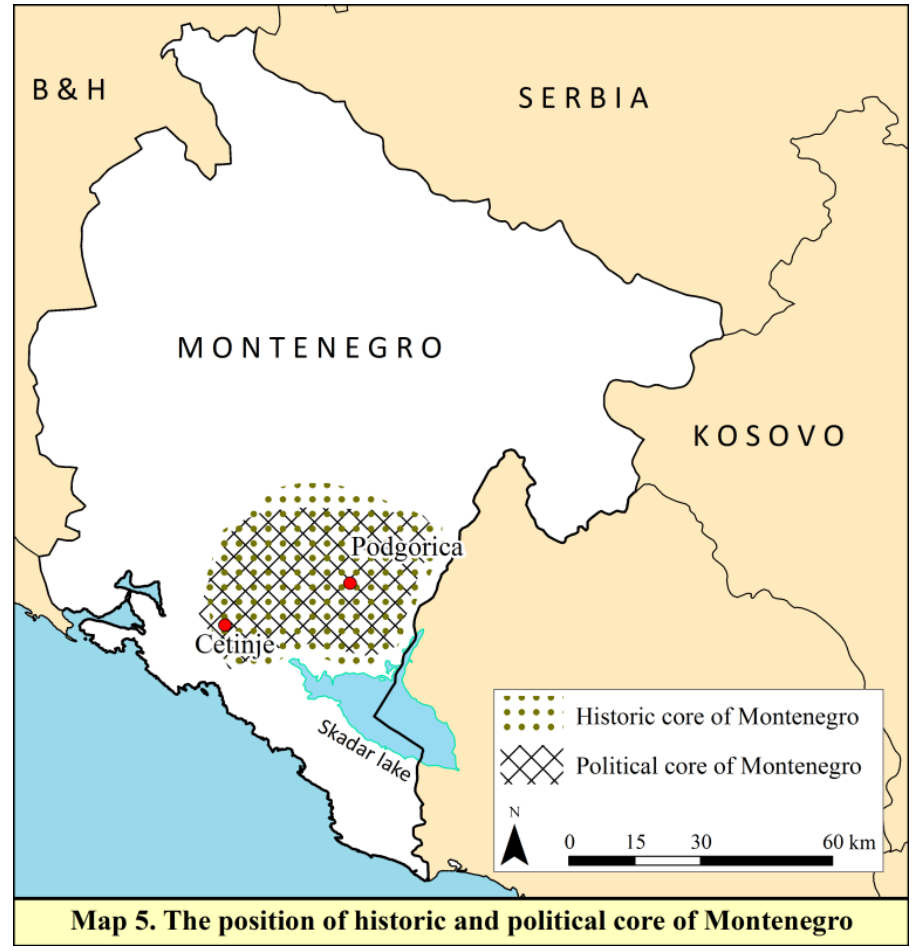

First, the Montenegrin nation, in relation to the neighbouring Serbs, is not conceived on ethno-religious but exclusively on the ethnic level, despite that the re-actualization of autocephaly Montenegrin Orthodox Church tries to ensure this kind of distinction, and even linguistic one. Second, in contrast to the Bosniaks, the Montenegrins have no ability to compensate the loss of potential members of their own nation within the country with ethnic Montenegrins outside the country. 


\section{MACEDONIANS}

Due to the fact that the area of Macedonia in the medieval Samuel's Empire had an important role and that in this time Ohrid represented an important political, spiritual and scientific centre, this analysis accepts the area of southwestern Macedonia as the historic core of this country [7]. Since that the deviation of the political core of modern Macedonia in relation to the historic core makes less than $200 \mathrm{~km}$, such deviation is going to be considered as minimal in comparison to the general scheme of the article, so it does not represent a significant exception from the hypothetical point of view that territorial conception of nation prevails in circumstances with no or minimal spatial deviation between the two cores.

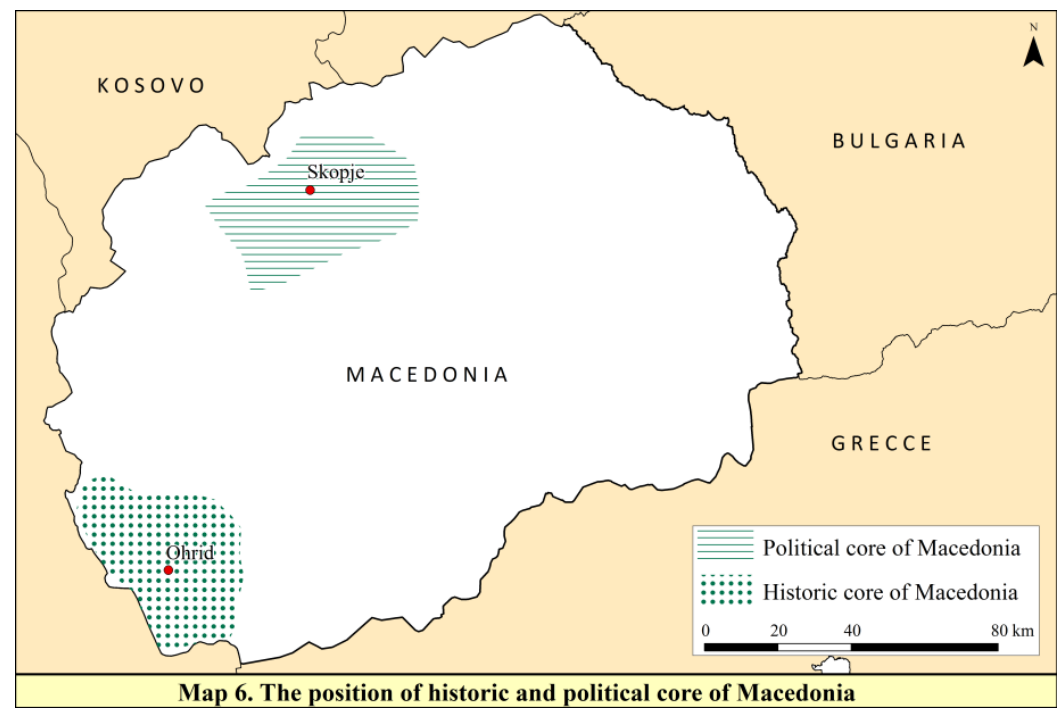

However, for Macedonian occasions this deviation is not completely negligible, but it is not considered as an important for overcoming of certain national conception. Indeed, the territorial conception of the Macedonian nation is primarily based on a strong regional identity and the lack of strong ethnic, linguistic and religious differences in relation to the neighbouring Slavic nations.

\section{CONCLUSION}

On the basis of separate analysis, article confirmed the basic hypothesis that overlapping of the historic and political cores generally causes the development of the territorial conception of South Slavic nations, with the partial exception of the Macedonians, while spatial deviation of these cores in all cases produces the ethnic conception of the nation. Also, in the case of the South Slavic nations with predominant ethnic national conception, there are noticeable past or present tendencies to territorial revisionism, while in the case of the territorial nations, the tendencies to reductionist identity and detention in their own historic and political cores, with the exception of Bosniaks' relations to Sandžak, can be noticed. 


\section{MAPS}

Map 1. The position of historic and political core of Slovenia

Map 2. The position of historic and political core of Croatia

Map 3. The position of historic and political core of Bosnia and Herzegovina

Map 4. The position of historic and political core of Serbia

Map 5. The position of historic and political core of Montenegro

Map 6. The position of historic and political core of Macedonia

\section{REFERENCES}

[1] Cohen, S. B. Geopolitics of the World System. Lanham: Rowman \& Littlefield Publishers, United States, 434 pp, 2003

[2] Smith, A. D. Nacionalizam i modernizam. Zagreb: Fakultet političkih znanosti, Croatia, $291 \mathrm{pp}, 2013$

[3] Štih, P. \& Simonitti, V. Slovenska povijest do prosvjetiteljstva. Zagreb: Matica hrvatska, Croatia, 475 pp, 2004

[4] Raukar, T. Hrvatsko srednjovjekovlje. Zagreb: Školska knjiga: Zavod za hrvatsku povijest Filozofskog fakulteta u Zagrebu, Croatia, 640 pp, 1997

[5] Filandra, Š. Bošnjaci nakon socijalizma. Sarajevo: BZK Preporod: Synopsis, Bosnia and Herzegovina, 463 pp, 2012

[6] Vrkatić, L. Pojam i biće srpske nacije. Novi Sad: Meditteran Publishing, Serbia, 872 pp, 2009

[7] Ћоровић, В. Историја Срба. Београд: Акиа Мали Принц, Serbia, 780 pp, 2014 